\title{
PENGEMBANGAN INSTRUMEN PENILAIAN SIKAP PRAKTIKUM FISIKA DASAR I PADA MAHASISWA JURUSAN PENDIDIKAN FISIKA UIN ALAUDDIN MAKASSAR
}

\author{
Anas Irwan*, Muhammad Arsyad, Kaharuddin Arafah \\ Program Studi Pendidikan Fisika UIN Alaudin Makassar \\ *Email: anas.irwan@uin-alauddin.ac.id.
}

\begin{abstract}
This research is a development research (research and development) which aims to analyze the results of the development of the instrument of assessment of Basic Physics I practicum for students majoring in Physical Education UIN Alauddin Makassar theoretically and empirically in order to obtain a valid, reliable and feasible assessment. The development of assessment instruments refers to the design of test instrument development according to Kaharuddin Arafah which consists of 7 steps of development, namely: (1) Determining the measuring scale, measuring objectives and construction of measuring instruments, (2) Construction outcome measuring instruments, (3) Validation of contents, (4) Temporary measuring instruments, (5) Target of respondents for the trial, (6) Reliability, and (7) Measuring instruments ready for use. This research was tested in the Department of Physics Education Semester I 2016/2017 UIN Alauddin Makassar. The results of the study were obtained from the Basic Physics I practicum assessment instrument that produced 8 valid items, theoretically with reliability 1.0 and empirically reliability of $73.60 \%$. The results of the study were obtained from the practicum assessment instrument that was declared valid and reliable and feasible to be used as a standard assessment instrument in the Department of Physics Education, UIN Alauddin Makassar.
\end{abstract}

Keywords: Assessment instrument, Basic Physics I practicum

\section{PENDAHULUAN}

Pendidikan merupakan bagian terpenting dalam pembangunan sumber daya manusia yang berkualiatas. Perkembangan Sumber daya manusia yang berkualitas di era teknologi diharapkan bisa memopang perkembangan di dunia pendidikan. Berdasarkan Indeks Pembangunan Manusia Indonesia (IPM) 2015 adalah 0,689. Menempatkan Indonesia dalam kategori pembangunan Indonesia menengah dan peringkat ke- 113 dari 188 negara dan wilayah (Isabel, 2017). Hal ini menunjukkan bahwa Indonesia harus berupaya keras untuk meningkatkan mutu pendidikannya.

Pendidikan saat ini ada tiga dimensi yang sangat penting dan saling berkaitan yaitu kurikulum, proses pembelajaran, dan sistem penilaian. Kurikulum merupakan suatu landasan program pembelajaran yang didalamnya berisi tujuan pembelajaran. Proses pembelajaran merupakan suatu upaya yang dilakukan oleh tenaga pendidik untuk mencapai tujuan dalam kurikulum. Penilaian merupakan alat bantu yang digunakan oleh peneliti untuk mengumpulkan data penelitian dengan cara melakukan pengukuran (Widoyoko \& Putro, 2016). Oleh karena itu, dalam program pembelajaran selain membutuhkan kurikulum juga sangat di butuhkan sistem penilaian yang baik dan tepat.

Penilaian digunakan pada semua tingkat pendidikan, mulai dari tingkat TK, SD, SMP, SMA sampai pada Perguruan Tinggi. Setiap tingkat pendidikan memiliki sistem penilaian yang berbeda dan memiliki taraf penilaian berbeda pula. Perguruan tinggi merupakan tingkat pendidikan yang paling tinggi dalam dunia Pendidikan, sebaiknya memiliki sistem penilaian yang sesuai dengan kemampuan mahasiswa dan mampu mengevaluasi sejauh mana mereka menetapkan hasil belajaranya.

Sistem penilaian dalam perguruan tinggi sangat berpengaruh pada kurikulum 
yang berlaku di Perguruan Tinggi tersebut. Perguruan Tinggi di Indonesia harus berbasis KKNI (Kerangka Kualifikasi Nasional Indonesia). Kurikulum tersebut diprioritaskan untuk perguruan-perguruan tinggi di Indonesia. Ada dua alasan dikembangkannya kurikulum berbasis KKNI, pertama alasan eksternal; 1) tantangan dan persaingan global, dan 2) ratifikasi Indonesia di berbagai konvensi. Kedua alasan internal: 1) kesenjangan mutu, jumlah, dan kemampuan, 2) relevansi penghasilan pengguna, 3) beragam aturan kualifikasi, dan 4) beragam pendidikan. Sehingga menghasilkan penilain kesetaraan dan pengakuan kualifkasi. Deskripsi capaian pembelajaran dalam KKNI terdiri dari tiga unsur, yaitu kemampuan kerja, penguasaan pengetahuan, serta wewenangan dan tanggung jawab.

KKNI sudah berlaku di jurusan Pendidikan Fisika sejak tahun 2014. Jurusan Pendidikan Fisika sudah menerapkan beberapa kurikulum yaitu kurikulum 2004, kurikulum 2008, kurikulum 2010 dan yang terakhir kurikulum 2014 berbasis KKNI hingga saat ini yang terintegrasi dengan kegiatan praktikum.

Kegiatan praktikum sangat diperlukan instrumen dan rubrik penilaian yang merangkum segala proses praktikum. Kehadiran rubrik penilaian dalam instrumen penilaian praktikum dapat menumbuhkan sikap percaya diri dan profesi guru dalam membina pengetahuan, sikap dan tindakan kreatif siswa. Keberhasilan ini tergantung dari kualitas asesmennya.

Asesmen yang berkualitas merupakan suatu komponen penting dalam penyelenggaraan sistem pendidikan yang bermutu. Sistem asesmen berfungsi sebagai pengontrol, mengendalikan, dan menyelaraskan komponen-komponen pendidikan yakni tujuan dengan standar proses, dan outcomes dengan kriteria pencapaian yang jelas, strategi, fasilitas dan komitmen yang terkait untuk mewujudkan pencapaian tujuan instrumen atau asesmen (Sudria et al. 2009).

Instrumen harus memenuhi kriteria validitas dan reliabilitas dalam mengukur kualitas dan mutu pendidikan khususnya kegiatan praktikum. Instrumen dikatakan valid apabila instrumen tersebut dapat diukur dengan tepat mengukur apa yang hendak di ukur. Sedangkan instrumen dikatakan dapat dipercaya (reliabel), jika memberikan hasil yang tetap atau ajeg (konsisten) apabila di diteskan berkali-kali (Widoyoko \& Putro, 2016).

Hasil penilaian yang sesuai dengan kemampuan mahasiswa secara tidak langsung bisa motivasi mahasiswa, ketika penilaian tersebut dilakukan secara terstruktur. Penilaian praktikum tidak hanya menilai psikomotor mahasiswa, tetapi aspek kognitif dan afektif juga perlu diberikan penilaian tersendiri. Menurut Gil-Madrona et al. (2016) bahwa dengan mengintegrasikan intervensi keterampilan dan nilai sosial di kelas dapat meningkatkan perkembangan peserta didik di domain afektif (These result support previons studies evidencing that integrating social skill and value intervention in the PE class inrease students' development in the affective domain). Penilaian yang dilakukan sebaiknya meliputi tiga aspek tersebut, sehingga semua kegiatan sebelum, selama dan sesudah praktikum dapat terangkum.

Observasi dan wawancara yang di lakukan peneliti di UIN Alauddin Makassar pada tanggal 11 Juni 2016 pada proses pelaksanaan praktikum Fisika Dasar diperoleh informasi bahwa sistem penilaian yang dilakukan oleh dosen yang bertugas di laboratorium belum didasari pada rubrik penilaian dengan baku dan belum mencakup afektif mahasiswa sebagaimana mestinya. Saat ini laboratorium Fisika hanya mempunyai kartu kontrol mahasiswa kegiatan praktikum yang memuat nilai 
respon, kegiatan praktikum dan nilai ujian laporan akhir. Artinya penilaian praktikum di Laboratorium hanya memuat nilai respon, keterampilan praktikum/ psikomotor, dan nilai ujian laporan akhir. Penilaian ini belum mempunyai perangkat penilaian yang baku dengan rubrik penilaian yang terstruktur. Penilaian sikap mahasiswa seakan dipandang sebelah mata yang lebih mengutamakan skill dan pengetahuan semata.

Dampak terlihat pada nilai akhir yang diperoleh mahasiswa. Nilai praktikum mahasiswa yang diperoleh dari dosen pengampu untuk mahasiswa semester ganjil angkatan 2015 dari 102 mahasiswa, 94 mahasiswa yang memperoleh nilai rata-rata diatas 65 dan 8 mahasiswa memperoleh nilai di bawah 65 . Berdasarkan hasil wawancara dengan dosen pengampuh, penilaian tersebut dilakukan belum efektif untuk melihat tingkat kemampuan afektif, dan kognitif mahasiswa.

Masalah disebabkan oleh beberapa faktor diantaranya, yaitu 1) kurang memadainya baik kualitas dan kuantitas tenaga laboratorium menyebabkan pemanfaatan laboratorium fisika belum optimal; 2) pedoman pensekoran dalam instrumen tidak jelas sehingga komponenkomponen yang dinilai sulit untuk diamati dan sukar digunakan; 3) penilai umumnya hanya satu orang yaitu dosen penanggung jawab, sedangkan komponen-komponen yang dinilai dan jumlah mahasiswa yang dinilai cukup banyak, sehingga sulit untuk mendapat pembanding yang dijadikan bahan pertimbangan mengambil keputusan; 4) kemungkinan ada kecenderungan untuk memberi nilai tinggi atau sebaliknya, hal ini di akibatkan oleh instrumen yang digunakan belum memenuhi persyaratan validitas dan reliabilitas.

Tehnik penilaian yang digunakan selama ini perlu adanya perbaikan atau perubahan agar lingkup pendidikan sesuai fungsi dan tujuan pendidikan nasional dapat terukur, terlihat, dan dapat dikembangkan dengan tepat. Tehnik penilaian yang mampu menunjukkan penilaian terhadap ranah kognitif, sikap dan psikomotor (Fitria \& Piniliah, 2013).

Penilaian mahasiswa yang mencakup tiga aspek tersebut merupakan penilaian sesungguhnya. Dalam penilaian, mahasiswa harus ikut serta didalamnya sehingga penilaian yang valid dan reliabel. Alasan yang menjadi dasar instrumen penilaian dapat diterapkan dalam kegiatan praktikum Fisika karena dalam melakukan penilaian mencakup aspek psikomotor, afektif dan kognitif. Hal ini mengacuh pada hakikatnya kemampuan mahasiswa tidak hanya dari bidang kognitif saja, tetapi ketiga aspek tersebut mahasiswa memiliki aspek kognitf, psiomotor dan afektif yang berbeda terhadap setiap perlakuan-perlakuan sehingga instrumen penilaian dapat di jadikan alat ukur untuk ketiga aspek tersebut dan diharapkan dapat meningkatkan kualitas psikomotor, kognitif dan afektif mahasiswa yang akan berdampak pada hasil belajarnya.

Pengembangan instrumen penilaian praktikum Fisika Dasar I diharapkan dapat memperbaiki kualitas kegiatan praktikum yang sebelumnya hanya mengukur kognitif, aktivitas /psikomotor dan laporan akhir mahasiswa dengan rubrik yang belum lengkap dan baku, diharapakan dengan pengembangan instrumen penilaian dapat menghasilkan produk instrumen penilaian yang lebih komprehensif yaitu penilaian reponsip/ kognitif beserta rubrik penilaian, penilaian sikap mahasiswa selama praktikum beserta rubrik penilaian, penilaian aktivitas/ psikomotor mahasiswa beserta rubrik penilaian, dan penilaian penulisan laporan lengkap/ akhir beserta rubrik penilaian sehingga dapat menilai apa yang ingin dinilai.

Berdasarkan keadaan tersebut, maka diperlukan suatu instrumen penilaian yang 
dapat mengukur seluruh keterampilan dalam melaksanakan praktikum. Hal ini sejalan dengan penelitian yang telah dilakukan oleh Riskawati (2015) bertujuan Pengembangan Perangkat Authentic Assessment dalam Praktikum Fisika Modern Prodi Pendidikan Fisika Unismuh Makassar. Namun pada penelitian ini lebih difokuskan pada instrumen penilaian mahasiswa dalam kegiatan praktikum Fisika Dasar I. Saefa Novitasari dan Lisdiana (2015) yang mengembangkan instrumen penilaian ranah afektif dan psikomotor pada Praktikum Struktur Hewan bahwa instrumen penilaian sangat layak, valid dan reliabel untuk diterapkan sebagai alat penilaian praktikum struktur tubuh hewan.

Selain itu, menurut penelitian yang telah dilakukan Sutrio et al. (2018) menjelaskan bahwa pengembangan bahan ajar fisika eksperimen berbasis proyek dapat meningkatkan keterampilan berpikir kritis calon guru fisika.

Selanjutnya, penelitian yang telah dilakukan Usman (2014), yang bertujuan mengembangkan perangkat penilaian Praktikum Fisika pada peserta didik SMP Unismuh Makassar, menunjukkan penilaian terhadap perangkat penilaian kinerja berada pada kategori baik dan telah memenuhi kriteria Valid dan Reliabel serta efesien dapat di gunakan oleh guru di SMP Unismuh Makassar. Selain itu, Rustam (2015) bertujuan mengembangkan instrumen penilaian praktik mengajar pada konstruk validitas dan reliabilitas termasuk dalam kategori tinggi. Misykat (2012) yang bertujuan mengembangkan instrumen pengukuran kecerdasan emosional siswa berbakat intelektual, diperoleh informasi dari tanggapan responden bahwa validitas dan reliabilitas yang baik.

\section{METODE PENELITIAN}

Jenis penelitian ini dikategorikan sebagai penelitian dan pengembangan (research and development). Penelitian dan Pengembangan yang dimaksud adalah penelitian yang dilakukan untuk menghasilkan instrumen penilaian sikap praktikum Fisika Dasar I.

Tempat yang dijadikan lokasi dalam penelitian adalah Jurusan Pendidikan Fisika UIN Alauddin Makassar. Subyek penelitian adalah mahasiswa Angkatan 2016/ 2017 dengan jumlah 80 orang mahasiswa. Pengembangan instrumen penilaian yang digunakan mengacu pada desain pengembangan instrumen tes menurut Kaharuddin Arafah yang terdiri 7 langkahlangkah pengembangan yaitu:

Menentukan skala ukur, sasaran ukur dan konstruksi alat ukur, (2) Alat ukur hasil konstruksi, (3) Validasi isi, (4) Alat ukur sementara, (5) Sasaran ukur responden uji coba, (6) Reliabilitas, dan (7) Alat ukur siap pakai.

Teknik analisis data untuk menganalisis data pada penelitian pengembangan instrumen penilaian ini digunakan tekhnik analisis statistik deskriptif.

\section{HASIL DAN PEMBAHASAN}

\section{Hasil Penelitian}

\section{a. Hasil Validitas Isi}

Hasil kegiatan pada tahap pengembangan menjadi acuan untuk menilai apakah instrumen yang telah dikembangkan memenuhi kriteria valid, dan reliabel.

Aspek yang dinilai dalam validasi lembar observasi dan rubrik penilaian sikap praktikum adalah kesesuaian materi, konstruk dan bahasa yang digunakan dalam instrumen penilaian sikap praktikum. Hasil analisis Gregory pada Tabel 1.

Tabel 1 menunjukkan bahwa keseluruhan instrumen penilaian dinilai baik. Dari Tabel 1 menunjukan bahwa penilaian sikap tersebut tergolong valid karena nilai validasi diperoleh nilai 1 sesuai dengan kriteria penilaian yang secara 
teoretis dinyatakan valid jika koefisien validitas isi tinggi yakni $>75 \%$.

Tabel 1. Hasil Analisis Gregory Instrumen Penilaian Sikap

\begin{tabular}{lllll}
\hline \multirow{2}{*}{ No } & Butir penilaian sikap & Nilai & \multicolumn{2}{c}{ Kriteria } \\
\cline { 3 - 5 } & & validasi & Valid & $\begin{array}{l}\text { Tidak } \\
\text { valid }\end{array}$ \\
\hline 1 & Butir 1 & 0,717 & Valid & 0 \\
\hline 2 & Butir 2 & 0,616 & Valid & 0 \\
\hline 3 & Butir 3 & 0,528 & Valid & 0 \\
\hline 4 & Butir 4 & 0,529 & Valid & 0 \\
\hline 5 & Butir 5 & 0,619 & Valid & 0 \\
\hline 6 & Butir 6 & 0,618 & Valid & 0 \\
\hline 7 & Butir 7 & 0,529 & Valid & 0 \\
\hline 8 & Butir 8 & 0,628 & Valid & 0 \\
\hline & Jumlah & & 8 & 0 \\
\hline
\end{tabular}

Sedangkan penilaian sikap tersebut tergolong reliabel karena semua nilai reliabel untuk penilaian sikap adalah diatas $75 \%$, sesuai dengan syarat reliabilitas. Dengan demikian, Validator menyimpulkan bahwa instrumen penilaian sikap praktikum dapat digunakan dengan revisi kecil.

\section{b. Hasil Validitas Kriteria Instrumen}

Data yang diperoleh saat uji coba dianalisis, kemudian hasilnya digunakan sebagai bahan pertimbangan untuk merevisi instrumen. Berikut ini gambaran data yang diperoleh dari hasil uji coba instrumen.

a) Hasil Validitas Kriteria tes Sikap

Penilaian dalam bentuk instrumen observasi untuk menilai sikap praktikum mahasiswa (ranah afektif) di ujicobakan pada mahasiswa jurusan Pendidikan Fisika UIN Alauddin Makassar angkatan 2016/2017. Data empirik yang diperoleh dari hasil uji coba, dijadikan dasar untuk melakukan uji validitas kriteria tiap butir, dan uji reliabilitas.

Tabel 2 menunjukan bahwa pada instrumen penilaian sikap pada uji coba memiliki koefisien korelasi skor butir terhadap skor totalnya yang lebih besar dari standar minimal 0,220, sehingga semua butir tersebut dinyatakan valid secara empirik. Dengan demikian, 8 butir memiliki korelasi skor butir terhadap skor totalnya signifikan dan dapat dinyatakan seluruhnya valid.

Tabel 2. Rekapitulasi Hasil Analisis Validasi Kriteria pada Uji Coba Tes Sikap

\begin{tabular}{|c|c|c|c|c|}
\hline \multirow{2}{*}{ Aspek } & \multicolumn{2}{|c|}{ Nilai } & \multicolumn{2}{c|}{ Kriteria } \\
\cline { 2 - 5 } & Validitas & $\begin{array}{c}\text { Reliabilitas } \\
(\%)\end{array}$ & Valid & Reliabel \\
\hline Sikap & 1 & 100 & Valid & Reliabel \\
\hline
\end{tabular}

Sedangkan, hasil analisis reliabilitas penilaian sikap dengan menggunakan metode Alpha Cronbach yang dibantu program SPSS diperoleh nilai koefisien reliabilitas sebesar 0,736 (koefisien alpha > 0,70 (Retnawati, 2016).

Berdasarkan Tabel 2 dapat diinterpretasikan bahwa $73,60 \%$ varians skor amatan diakibatkan oleh varians skor sejati kelompok individu dan korelasi antara skor teramati dan skor sejati sama dengan 0,736 sehingga instrumen tes afektif berada pada kategori reliabel.

\section{Pembahasan}

Hasil penelitian pengembangan yang telah dilakukan untuk menilai instrumen penilaian yang telah dikembangkan apakah telah memenuhi kriteria kevalidan baik secara teoretik maupun secara empirik. Dari hasil penelitian tersebut dijadikan sebagai dasar untuk menarik kesimpulan bahwa instrumen penilaian praktikum Fisika Dasar I berkualitas atau tidak.

Adapun uraian kriteria perangkat pembelajaran yang telah dikembangkan sebagai berikut:

\section{a. Kevalidan Teoretik Instrumen}

Hasil analisis kevalidan instrumen penilaian praktikum yang merupakan penilaian pakar/ ahli terhadap instrumen yang telah dikembangkan melalui validasi isi instrumen penilaian sikap beserta rubrik penilaiannya. Berdasarkan hasil analisis validasi isi, diperoleh bahwa aspek sikap mahasiswa menghasilkan 8 butir yang valid dengan relibilitas $100 \%$. Nilai validasi 
berada dalam batas $\mathrm{V}_{\mathrm{c}}>0,7$ yang artinya keseluruhan instrumen berada pada kategori valid dengan reliabilitas $R>75 \%$ artinya berada pada kategori reliabel.

Berdasarkan hasil penelitian tersebut dapat disimpulkan bahwa keseluruhan instrumen penilaian praktikum telah memenuhi kriteria kevalidan isi dan kriteria reliabilitas. Kedua validator juga menyatakan bahwa instrumen penilaian yang telah dikembangkan dapat digunakan dengan revisi kecil, sehingga dilakukan revisi berdasarkan saran dari kedua validator. Penilaian hasil telaah validasi isi oleh pakar telah memberi kesimpulan bahwa secara teoretis tes yang dikembangkan dari aspek konstruksi dan bahasa yang digunakan dalam penyusunan tes telah memenuhi aspek ketepatan dan kejelasan dalam proses penyusunannya dengan sedikit revisi. Hal ini memberikan gambaran bahwa hasil uji validasi isi sebelum ujicoba mengungkapkan ketepatan butir soal mengukur indikator telah dianggap valid secara teoretik dan ketepatan butir-butir pengamatan terhadap penilaian afektif dan psikomotor.

Adapun saran-saran validator meliputi: 1) alokasi waktu harus dicermati kembali untuk semua topik percobaan, 2) penggunaan kata operasional pada setiap butir soal perlu diperhatikan antara butir soal dengan kisi-kisi soal, 3) penyajian rubrik dan struktur bahasa yang baku dan jelas petunjuknya yang disesuaikan dengan topik percobaan. Setelah dilakukan revisi maka instrumen penilaian praktikum ini dapat digunakan dalam kegiatan praktikum di Laboratorium.

\section{b. Kevalidan Empirik Instrumen Penilaian}

Hasil kevalidan empirik atau validitas kriteria yang telah dirancang diambil dari hasil uji coba instrumen penilaian praktikum Fisika Dasar I, yaitu hasil uji coba terhadap mahasiswa yang menggunakan instrumen penilaian tersebut dengan mengisi lembar observasi yang di isi oleh observer untuk menilai sikap praktikan selama praktikum di dalam laboratorium. Hasil analisis uji coba lapangan dilakukan dengan menghitung reliabilitas instrumen agar data hasil uji coba layak digunakan untuk penilaian tingkat keterpercayaan atau kehandalan alat ukur yang telah dikembangkan.

Hasil analisis empirik instrumen penilaian yang telah dilakukan uji coba pada angkatan 2016 dengan jumlah 80 orang, menghasilkan instrumen sikap selama praktikum mahasiswa menghasilkan 8 butir valid dengan reliabilitas $73,60 \%$. Hal ini berarti instrumen yang telah dikembangkan dapat secara empirik digunakan dalam kegiatan praktikum khususnya praktikum Fisika Dasar I UIN Alauddin Makassar. Hal juga serupa dengan penelitian yang telah dilakukan oleh Herayanti et al, (2017), diperoleh bahwa instrument yang telah di validasi secara emprik terhadap produk dengan sekala yang lebih luas.

\section{c. Temuan Khusus}

Temuan khusus yang dianggap berkonstraksi dalam penelitian ini antara lain:

a. Pada saat uji coba pertemuan pertama, ketika praktikan melakukan percobaan di Laboratorium merasa canggung dan tidak ada yang mau maju memegang alat dan mempraktikkan percobaan yang akan dilakukan pada hal sudah dipelajari secara teori ketika respon sebelum masuk praktikum. Namun setelah mereka mengikuti praktikum percobaan dengan sistem penilaian yang sistematis, barulah mereka menyadari akan manfaat instrumen penilaian praktikum ini. Bahkan antusias praktikan atau mahasiswa terlihat pada saat sudah terbiasa dengan sistem penilaian, mereka justru mau semua turut aktif di dalamnya 
di setiap langkah-langkah kegiatan di Laboratorium.

b. Perbedaan antara sebelum dan setelah pengembangan instrumen dapat di lihat dari instrumennya yaitu:

1) Instrumen Penilaian sebelumnya

a) Indikator kelulusan mahasiswa dari kegiatan praktik laboratorium Fisika Dasar sepenuhnya dari tiga aspek responsip, kegiatan praktik/ psikomotor dan laporan akhir.

b) Penilaian praktik tanpa lembar observasi dan rubrik penilaian yang jelas.

c) Tidak dilengkapi rubrik penilaian yang baku dan bergantung sepenuhnya pada asisten yang membimbing.

2) Instrumen Penilaian yang dikembangkan

a) Indikator kelulusan mahasiswa dari kegiatan praktik laboratorium Fisika Dasar merupakan akumulasi dari nilai responsip/ kognitif, sikap mahasiswa, psikomotor (praktik), dan penulisan laporan lengkap praktikum.

b) Penilaian sikap mahasiswa selama di laboratorium terukur dengan lembar observasi dan rubriknya.

\section{d. Kendala-Kendala yang dialami selama Penelitian}

Ada beberapa kendala yang dialami selama kegiatan pengembangan, terutama kegiatan uji coba. Kendala-kendala yang dimaksud adalah sebagai berikut:

a. Pengamat (observer) merasa kesulitan dalam melakukan kegiatan pengamatan pada waktu bersamaan, walaupun sebelum uji coba diberikan petunjuk melakukan pengamatan.

b. Pengelolaan waktu yang telah di alokasikan antara mengerjakan soal responsip dan kegiatan praktikum masih terasa sulit di capai secara maksimal sehingga peneliti menambah alokasi waktunya di lapangan disebabkan ada beberapa percobaan yang membutuhkan porsi alokasi waktu yang lebih banyak.

c. Pada saat uji coba, mahasiswa/ praktikan dan asisten masih terkendala mengubah sikap kebiasaan sebelumnya belum terbiasa menggunakan instrumen penilaian praktikum.

\section{e. Keterbatasan Penelitian}

Tujuan penelitian ini adalah untuk menghasilkan instrumen penilaian praktikum Fisika Dasar I dengan langkahlangkah pengembangan menurut Kaharuddin Arafah (2016) tersebut dihasilkan instrumen penilaian yang Valid dan Reliabel. Akan tetapi dalam penelitian ini, penulis menyadari pengembangan ini terdapat beberapa keterbatasan yaitu uji coba lapangan yang sesungguhnya hanya dilakukan pada satu kelompok saja, pada hal untuk mendapatkan masukan yang lebih banyak seharusnya uji coba lapangan tidak hanya dilakukan hanya pada satu kelompok saja akan tetapi di ujicobakan pada beberapa kelompok.

Sahidu et al. (2018), menjelaskan bahwa Penelitian sebenarnya tidak hanya disebabkan oleh instrument untuk meningkatkan kualitas pembelajaran, tetapi juga disebabkan oleh kreativitas Guru atau Dosen dalam menggunakan produk yang telah dikembangkan

\section{PENUTUP}

Berdasarkan hasil dan pembahasan maka diperoleh kesimpulan sebagai berikut:

1. Hasil pengembangan instrumen penilaian sikap praktikum Fisika Dasar I pada mahasiswa jurusan Pendidikan Fisika UIN Alauddin Makassar secara teoretis yaitu menghasilkan 8 butir valid dengan reliabilitas 1,0; sehingga berdasarkan secara teoritis berada pada kategori valid dan reliabel.

2. Hasil pengembangan instrumen penilaian sikap praktikum Fisika Dasar I 
pada mahasiswa jurusan Pendidikan Fisika UIN Alauddin Makassar secara empirik yaitu menghasilkan 8 butir valid dengan reliabilitas $73,60 \%$ sehingga secara empirik dapat dinyatakan memenuhi aspek validitas dan reliabilitas yang baik dan layak untuk digunakan sebagai instrumen penilaian yang baku.

\section{REFERENSI}

Arafah, Kaharuddin. 2016. Makalah Teori dan Evaluasi Pembelajaran. Makalah di sajikan Seminar Program Studi Pendidikan Fisika, Pps UNM Makassar Tahun 2016.

Fitria, Piniliah, W. 2013. Pengembangan Instrumen Penilain Produk pada Pembelajaran IPA untuk SMP. Jurnal Pendidikan Fisika (Online), Univ.Sebelas Maret Surakarta, 1(2), 23.

Gil-Madrona, P., Samalot-Rivera, A., \& Kozub, F. M. (2016). Acquisition and transfer of values and social skills through a physical education program focused in the affective domain. Motricidade, 12(3), 32-38.

Herayanti, L., Fuaddunnazmi, Muhammad, \& Habibi. 2017. Pengembangan Perangkat Pembelajaran Fisika Berbasis Moodle. Jurnal Pendidikan Fisika dan Teknologi, 3 (2), 197-206.

Ibrahim, Misykat Malik. 2012. Pengembangan Instrumen Pengukur Kecerdasan Emosional Siswa Berbakat Intelektual. Jurnal Evaluasi Pendidikan, 3(2), 1-21.

Isabel D. 2017. Indeks Pembangunan Manusia Meningkat tetapi Kesenjangan Masih Tetap Ada. Diakses $27 \quad$ Mei 2017. www.undp.org/content/indonesia-shuman-development-indekx-risesbut-inequality-remains-html.

Novitasari, S. \& Lisdiana. 2015. Pengembangan Instrumen Penilaian Ranah Afektif Dan Psikomotor Pada
Mata Kulaih Praktikum Struktur Hewan. Unnes Jounal of Biology Education (Online), 4(1).

Retnawati, H. 2016. Validitas Reliabilitas \& Karakteristik Butir (Panduan untuk Peneliti, Mahasiswa dan Psikometri). Yogyakarta: Parama Publishing.

Riskawati. 2015. Pengembangan Perangkat Authentic Assessment dalam Praktikum Fisika Modern Prodi Pendidikan Fisika Unismuh Makassar. Tesis. Tidak diterbitkan. Makassar: PPs UNM.

Rustam. 2015. Pengembangan Instrumen Penilaian Praktik Mengajar Mahasiswa Program Pendidikan Guru Sekolah Dasar Universitas Terbuka. Sinopsis Disertasi. Tidak diterbitkan. Jakarta: Program Pascasarjana UNJ.

Sahidu, Hairunnisyah, dkk. 2018. Pengembangan Perangkat Pembelajaran Fisika Berorientasi Pada Kreativitas Calon Guru. Jurnal Pendidikan Fisika dan Teknologi, 4(1), $1-6$.

Sudria, Nyoman, I. B \& Manimpa. 2009. Pengembangan Rubrik Penilaian Keterampilan Dasar Praktikum. Jilid 42. No.3 Oktober 2009, Halaman 222-233.

Sutrio, S., Gunawan, Harjono, A., \& Sahidu, H. 2018. Pengembangan Bahan Ajar Fisika Eksperimen Berbasis Proyek Untuk Meningkatkan Keterampilan Berpikir Kritis Calon Guru Fisika. Jurnal Pendidikan Fisika dan Teknologi, 4(1), 131-140.

Usman. 2014. Pengembangan Perangkat Penilaian Kinerja Praktikum Fisika Pada Peserta Didik SMP Unismuh Makassar), Jurnal Pendidikan Fisika UNM, 10(3), 274 - 284.

Widoyoko, S \& Putro, E. 2016. Teknik Penyusunan Instrumen Penelitian. Yogyakarta: Pustaka Pelajar. 